\title{
Isolation, Characterization and Molecular Identification of Culturable Gut Bacteria in Diamondback Moth, Plutella xylostella (Linnaeus)
}

\author{
W. Vijaykumar ${ }^{1 *}$, R. Muthuraju ${ }^{1}$, B. Shivanna ${ }^{2}$, K. Archana ${ }^{1}$ and B.S. Nalini ${ }^{1}$ \\ ${ }^{1}$ Department of Agricultural Microbiology, ${ }^{2}$ Department of Agricultural Entomology, \\ University of Agricultural Sciences, Bengaluru-560065, India \\ *Corresponding author
}

A B S T R A C T

\begin{tabular}{|c|c|}
\hline Keywords & $\begin{array}{l}\text { Diamondback moth, Plutella xylostella is a major pest of cruciferous crops worldwide and } \\
\text { it has developed resistance to almost all synthetic insecticides. It was known to harbour }\end{array}$ \\
\hline $\begin{array}{l}\text { Diamondback moth } \\
\text { (DBM), } \\
\text { Endosymbionts, } \\
\text { Catalase and } \\
\text { IMVIC tests, } 16 \mathrm{~S} \\
\text { rRNA, Serratia spp }\end{array}$ & $\begin{array}{l}\text { microorganisms which play important role in growth and development of the host. In the } \\
\text { present study bacterial strains were isolated from third instar larvae of } P \text {. xylostella } \\
\text { collected from Sugatur, Kolar District of the state Karnataka. Morphological and } \\
\text { Biochemical characterization were done, among them most of the bacterial isolates were } \\
\text { gram negative and negative for some biochemical tests. Further, total bacterial genomic } \\
\text { DNA was extracted from the bacterial isolates and amplified using PCR with 16S rRNA }\end{array}$ \\
\hline Artic & \\
\hline $\begin{array}{l}\text { Accepted: } \\
\text { 22 January } 2019 \\
\text { Available Online: } \\
10 \text { February } 2019\end{array}$ & $\begin{array}{l}\text { nematodiphila (DBM2), Serratiasp. (DBM3) and Myroidesodoratus (DBM4). The } \\
\text { Serratia spp. is the most predominant bacterial isolate in this region. These studies } \\
\text { suggested that a combination of molecular and traditional culturing methods can be } \\
\text { effectively used to analyze and determine the diversity of gut microflora. These bacterial } \\
\text { strains may play important roles in growth and development of } P \text {. xylostella. }\end{array}$ \\
\hline
\end{tabular}

\section{Introduction}

Diamondback moth, Plutella xylostella (L.) (Lepidoptera: Plutellidae) is the most important destructive pest of the cruciferous vegetables like brassica, cabbage, cauliflower, radish, knol-khol, turnip, mustard and amaranthus in many parts of the world (Saeed et al., 2010). The developing resistance and decline of insecticide efficiency against DBM become a limiting factor in cultivation of commercial crops like cabbage and cauliflower in India. Insect system harbors a wide range of microbial community (Hunt and Charnley, 1981). Microorganisms play an important role in the growth and development of insects. Microbial symbionts provide an diverse range of benefits in insect nutrition, e.g. by providing essential amino acids, digestive enzymes or vitamins (Brune, 2014). 
The insects created opportunities for bacteria, and these bacteria occupy right niches in host bodies. The interactive relationship between microbiota and their host exist, and these coevolution of microorganisms and their insect hosts led to a stable mutualistic relationship (Genta et al., 2006). The diversity of insects is reflected in large and varied microbial communities inhabiting the gut (Dillan and Dillan, 2004). The most important beneficial function of the indigenous intestinal microbiota is their ability to withstand the colonization of the gut by non-indigenous species including pathogens and therefore prevent enteric infections (Berg, 1996), such as gut bacteria could mediate disease resistance and fight against damage from bad factors in host insects (Dillon and Charnley, 1996). Besides, the insect gut bacteria can cause insects population changes and phenotype manipulation (Rajagopal, 2009).

Lin et al., (2014) collected different life stages (fourth instar larvae, pupae and adults) of the Diamondback moth, P.xylostella, to find out different microbial abundance and diversity of gut bacteria. A large quantity of bacteria was found in all life stages, out of which higher quantity of bacteria was found in larval gut. Firmicutes bacteria, Bacillus sp., were the most dominant species in every life stage. Phylogenetic analysis showed the sequences of the bacteria belonged to the Actinobacteria, Proteobacteria and Firmicutes. Serratia sp. in proteobacteria was abundant in the larval gut. Their study also suggested that a combination of molecular and traditional culturing methods can be effectively used to analyze and to determine the diversity of gut microflora.

\section{Materials and Methods}

\section{Collection and mass rearing of DBM}

The field caught population of DBM larvae were collected from the cabbage field of
Sugatur village, Kolar District of Karnataka. This region is predominantly cabbage growing region of South Karnataka. The collected populations were brought to the laboratory and reared on mustard seedlings raised in plastic ice cream cups $(8 \times 4 \mathrm{~cm})$ by adopting the method described (Liu and Tzeng, 1984) with suitable modifications. The rearing procedure was continued for at least one generation till sufficient number of larvae was available for further studies.

\section{Isolation and characterization of gut bacteria}

The third instar larvae of DBM were selected, starved for 24 hours and surface sterilized with $70 \%$ ethanol for 1 minute followed by $0.1 \%$ sodium hypochlorite for 1 minute, then rinsed with sterile distilled water for 2 to 3 times to remove the external microflora. Gut homogenate $(100 \mu \mathrm{l})$ were plated on Nutrient Agar (NA) and Luria Bertani (LB) media in three replicates and incubated at $30^{\circ} \mathrm{C}$ for $48 \mathrm{~h}$ and surveyed every $24 \mathrm{~h}$ for new colonies. The colonies were differentiated based on size, shape, color, margin and morphology and a single representative isolate of each morphotype transferred to new plates and made pure culture.

\section{Biochemical characterization of isolated bacteria}

The isolates were gram stained and subjected to basic biochemical characterization, including catalase and IMVIC reaction. IMVIC reactions consist of Indole production test in tryptone broth, after adding kovac's reagent, cherry red ring on the top layer of broth indicates the production of indole (positive). Methyl Red and Voges Proskauer tests in an MR-VP broth, for methyl red test, after adding methyl red, the production of red colour indicates the positive result and having ability to oxidize glucose. For Voges 
Proskauer, VP reagent 1 and 2 were added, and then pinkish red color appeared which indicates the positive result. Citrate utilization test in Simmons Citrate Agar, changes in color as an indicator in the media, which is from green to blue, indicates positive for this test and Catalase test in trypticase soy agar media, formation of bubbles after adding hydrogen peroxide indicates positive result for this test (Benson, 2002).

\section{Molecular identification}

\section{DNA extraction and PCR amplification}

The isolates were multiplied in LBbroth and the genomic DNA isolated by CTAB (CetylTrimethyl Ammonium Bromide) lysis method. Isolated bacteria were multiplied in LB broth. Pellet was obtained by centrifugation at $10000 \mathrm{rpm}$ for 1 minute and was resuspended in TE buffer, SDS, RNase, Proteinase $\mathrm{K}$ and lysozyme was added. Tubes were kept in hot water bath for 30 minutes at $65^{\circ} \mathrm{C}$. The $5 \mathrm{M} \mathrm{NaCl}$ and $\mathrm{CTAB}$ buffer was added, then incubated in hot water bath for 30 minutes at $65^{\circ} \mathrm{C}$.Equal volume of Chloroform: Isoamyl alcohol (24:1) was added and were centrifuged for 5 minutes at $10000 \mathrm{rpm}$. Supernatant was transferred to a new tube and added equal volume of Phenol: Chloroform: Isoamyl alcohol (25:24:1), then centrifuged for 5 minutes in $10000 \mathrm{rpm}$. The DNA was precipitated by adding $600 \mu \mathrm{l}$ of chilled isopropanol and centrifuged after overnight incubation. The pellet was washed with of 70 $\%$ chilled ethanol, air dried and dissolved in $80 \mu 1$ of TE buffer.

The isolated DNA was checked for quantity with $1 \%$ agarose gel. Then, the DNA will be amplified in PCR with 16S rRNA gene with having primers (Fp1: GAGTTTGATC CTGGTCA and Rp2: ACGGCTACCTTGTT ACGACTT). PCR conditions were as follows: Initial denaturation at $94{ }^{\circ} \mathrm{C}$ for 4 mins, 35 cycles of denaturation at $94{ }^{\circ} \mathrm{C}$ for 1 min, annealing at $60{ }^{\circ} \mathrm{C}$ for $30 \mathrm{sec}$, extension at $72{ }^{\circ} \mathrm{C}$ for $1 \mathrm{~min}$ and final extension at 72 ${ }^{\circ} \mathrm{C}$ for 10 mins. Initial denaturation at $94{ }^{\circ} \mathrm{C}$ for 3 mins, 35 cycles of denaturation at $94{ }^{\circ} \mathrm{C}$ for $1 \mathrm{~min}$, annealing at $60{ }^{\circ} \mathrm{C}$ for $1 \mathrm{~min}$, extension at $72{ }^{\circ} \mathrm{C}$ for $1 \mathrm{~min}$ and final extension at $72{ }^{\circ} \mathrm{C}$ for 2.5 mins. The amplified unpurified PCR products were verified with agarose gel $(1 \%)$ electrophoresis and purified. The obtained nucleotide sequences were submitted to the National Centre for Biotechnology Information (NCBI) (http://www.ncbi.nlm.nih.gov/BLAST) database.

\section{Phylogenetic analysis}

The phylogenetic analysis was performed with nucleotide sequences using molecular evolutionary genetic analysis (MEGA 7), after multiple alignment of the data by CLUSTAL W. the tree was constructed using closely related sequences using neighbor joining algorithm. Based on maximum query coverage the bacterial species was identified.

\section{Results and Discussion}

\section{Isolation and characterization gut bacterial isolates}

The totally ten bacterial isolates were obtained based on their morphology, six bacteria in the nutrient agar media and four bacteria in LB media showed in Table 1. The bacterial isolates were predominantly slightly dry texture, raised, pasty looking, white in color. Some colonies were irregular, concave, yellow color and others were smooth, circular, creamy white color. Most of the isolates were rod shaped, gram negative bacteria. Among ten isolates, three isolates were positive and seven were negative for gram reactions. Six isolates were rod shaped and four were cocci shaped bacteria. 
Biochemical characterization of isolated bacteria

The almost same type of bacterial colonies were analysed through morphological character. Therefore, all the bacterial isolates were subjected for biochemical characterization. Most of the isolates predominantly showed positive results for IMVIC test except catalase test which get positive result for only one isolate. Among ten isolates, five isolates had positive result and remaining five had negative results for indole production test. Methyl red testing was positive for six isolates and negative for four isolates. Three isolates were positive and seven isolates were negative for Vogesproskauer. Five Isolates had positive and five isolates had negative results on citrate test. Only one isolate showed positive result and remaining nine isolates showed negative results for catalase test (Table 2). For further confirmation and identification of isolates, molecular identification was performed (Fig. 1).

\section{Molecular identification of bacterial isolates}

In total, five bacterial isolates from larvae were identified and sequenced. The genomic DNA was isolated from six bacterial isolates. The thick DNA bands were visualized on agarose gel under gel documentation photograph represents the presence of DNA and which was subjected to PCR amplification in thermocycler with 16S rRNA primers. The amplified product was expected $1000 \mathrm{bp}$ in size. The molecular identification indicated that the genus Serratia was invariably associated in third instar larvae of DBM. The bacterial isolates were identified as Serratia marcescens (DBM1 and DBM5), Serratia nematodiphila (DBM2), Serratiasp. (DBM3) and Myroides odoratus (DBM4) (Table 3 and Fig. 2 and 3).

Table.1 Morphological features of bacterial isolates from larvae of DBM

\begin{tabular}{|c|c|c|c|c|}
\hline SI. No. & Isolates & Colony morphology & Cell shape & Gram reaction \\
\hline DBM 1 & $10^{-3} \mathrm{R}_{3}, \mathrm{I}_{1}$ & $\begin{array}{l}\text { Round, regular, } \\
\text { dark yellow }\end{array}$ & Straight Rod & Negative \\
\hline DBM 2 & $10^{-3}, \mathrm{R}_{3}, \mathrm{I}_{3}$ & Yellow & Cocci & Positive \\
\hline DBM 3 & $10^{-5}, \mathrm{R}_{1}, \mathrm{I}_{2}$ & White & Cocci & Positive \\
\hline DBM 4 & $10^{-3}, \mathrm{R}_{3}, \mathrm{I}_{2}$ & Light yellow & Cocci & Negative \\
\hline DBM 5 & $10^{-3}, \mathrm{R}_{3}, \mathrm{I}_{4}$ & Opaque, irregular, White & Rod & Negative \\
\hline DBM 6 & $10^{-3}, \mathrm{R}_{2}, \mathrm{I}_{5}$ & $\begin{array}{l}\text { Large, irregular, } \\
\text { convex, White }\end{array}$ & Rod & Positive \\
\hline DBM 7 & $10^{-3}, \mathrm{R}_{3}, \mathrm{I}_{1}$ & Large, concave, White & Rod & Negative \\
\hline DBM 8 & $10^{-3}, \mathrm{R}_{3}, \mathrm{I}_{2}$ & $\begin{array}{c}\text { Filamentous, Creamy } \\
\text { dark yellow }\end{array}$ & Rod & Negative \\
\hline DBM 9 & $10^{-3,} \mathrm{R}_{2}, \mathrm{I}_{1}$ & $\begin{array}{l}\text { Small, round, } \\
\text { mucoidWhite }\end{array}$ & Rod & Negative \\
\hline DBM 10 & $10^{-3,} \mathrm{R}_{2}, \mathrm{I}_{2}$ & Creamy yellow & Cocci & Negative \\
\hline
\end{tabular}


Table.2 Biochemical features of bacterial strains isolated from larvae

\begin{tabular}{|l|c|c|c|c|c|}
\hline SI. No. & $\mathbf{1}$ & $\mathbf{2}$ & $\mathbf{3}$ & $\mathbf{4}$ & $\mathbf{5}$ \\
\hline DBM 1 & + & + & - & - & - \\
\hline DBM 2 & + & + & - & - & - \\
\hline DBM 3 & - & - & + & + & - \\
\hline DBM 4 & - & - & - & - & - \\
\hline DBM 5 & - & + & + & + & - \\
\hline DBM 6 & + & + & - & - & - \\
\hline DBM 7 & - & + & - & + & - \\
\hline DBM 8 & + & - & - & - & - \\
\hline DBM 9 & - & + & + & + & + \\
\hline DBM 10 & + & - & - & + & - \\
\hline
\end{tabular}

1. Indole production test, 2. Methyl red test, 3. Voges proskauer test, 4. Citrate utilization test, 5. Catalase test. + - Positive, - - Negative

Table.3 Identified bacterial isolatesin larvae

\begin{tabular}{|l|l|l|}
\hline \multicolumn{1}{|c|}{ Isolate } & Identified bacterial endosymbionts & Gene bank accession number(s) \\
\hline DBM1 & Serratiamarcescens & MK044840 \\
\hline DBM5 & Serratia nematodiphila & MK044841 \\
\hline DBM7 & Serratiasp. & MK044842 \\
\hline DBM8 & Myroidesodoratus & MK044843 \\
\hline DBM9 & Serratiamarcescens & MK044844 \\
\hline
\end{tabular}

Fig.1 Biochemical characterization of isolated bacteria of Diamondback moth (Plutella xylostella)

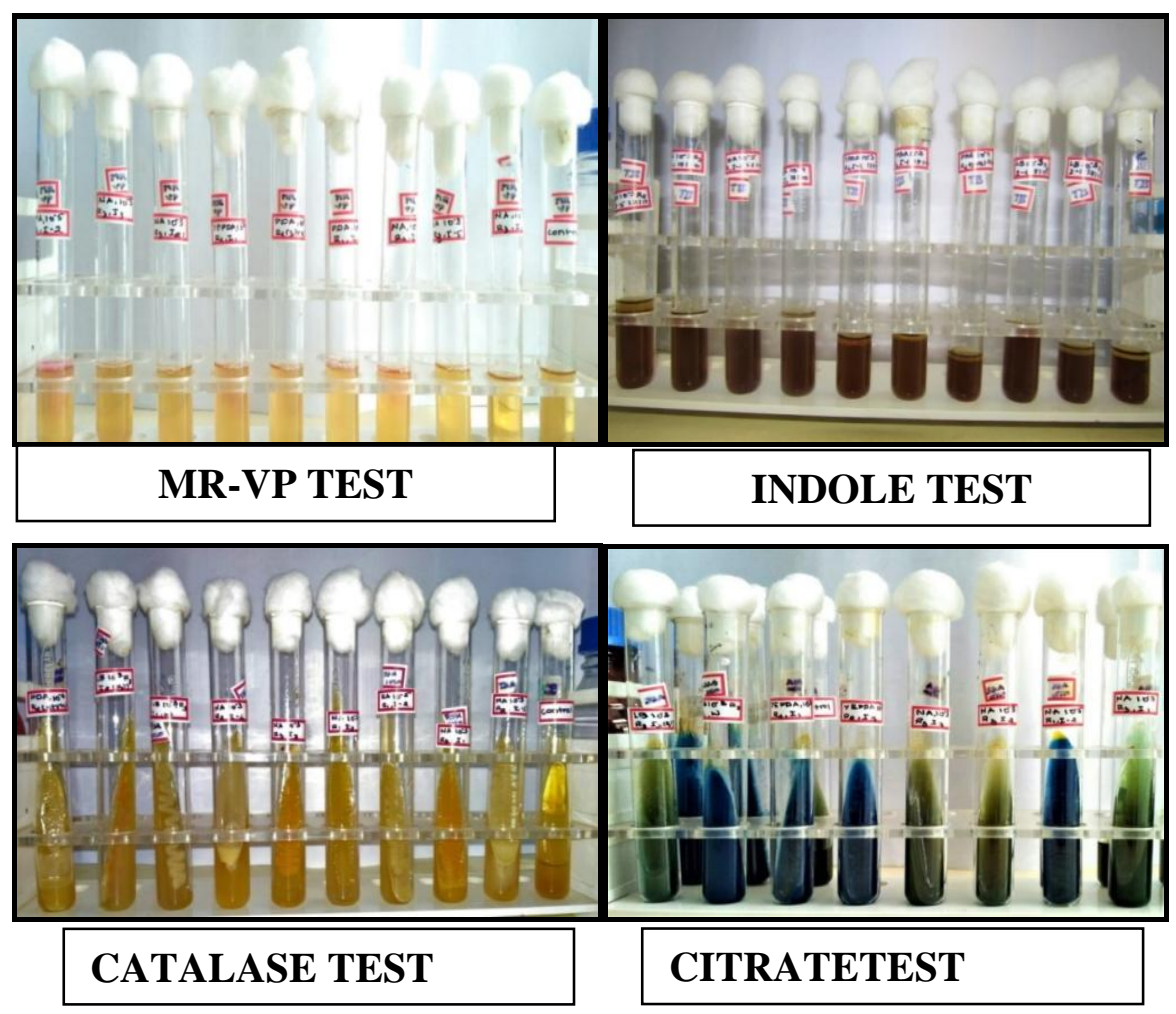


Fig.2Agarose gel showing amplification of 1000 bp gene corresponding to $16 \mathrm{~S}$ rRNA, MMarker DNA-1000bp: First population

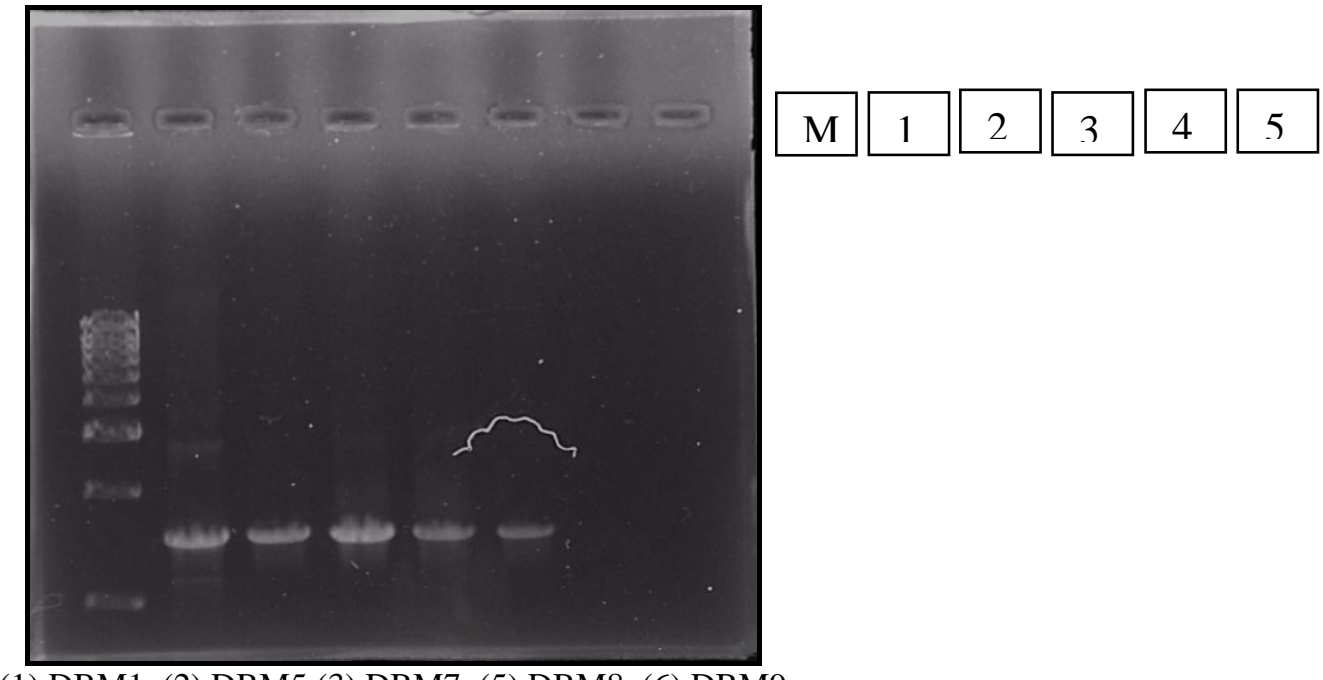

(1) DBM1, (2) DBM5,(3) DBM7, (5) DBM8, (6) DBM9

Fig.3 Phylogenetic tree of bacterial strains isolated from $P$. xylostella

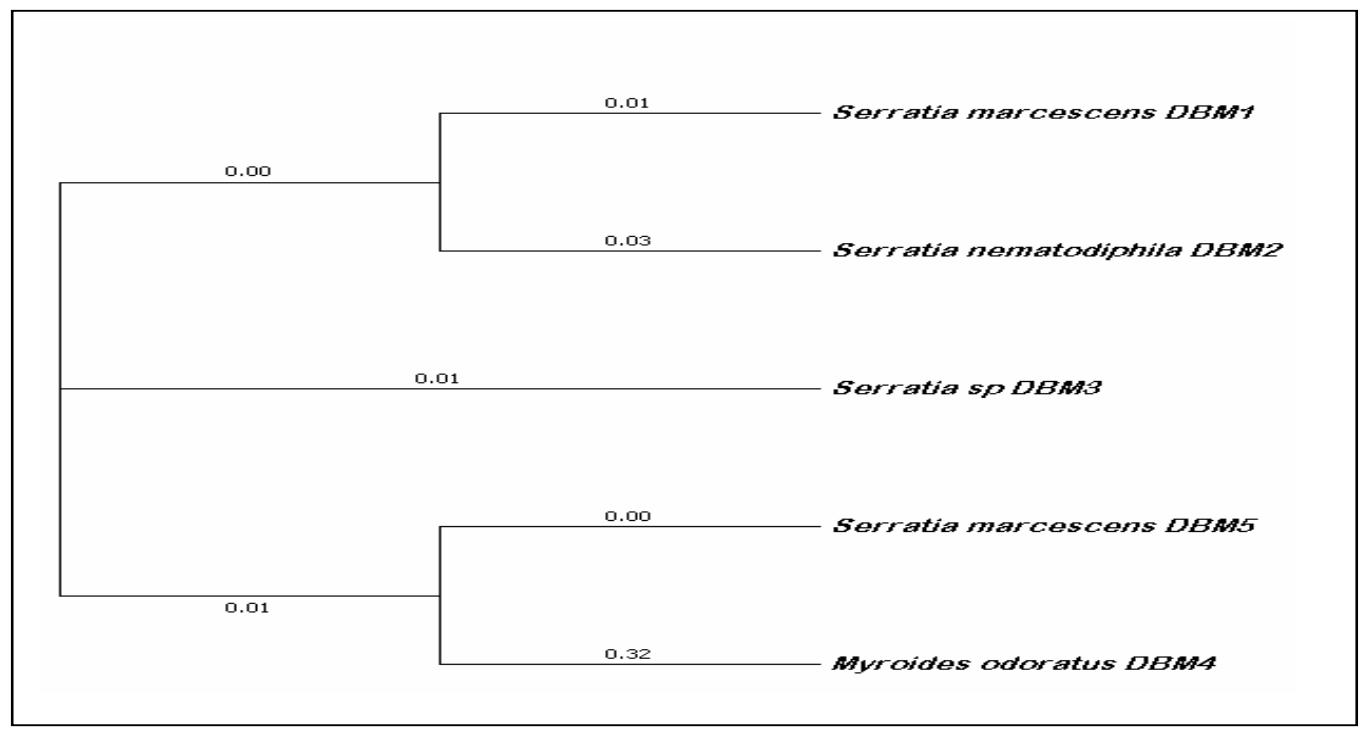

Only less than one percent of bacteria could be cultured, even though, feed process such as feeding on different host plants, medium component and culture time affected culturable bacteria species, a few strains detected in the larval gut might be just existed in the environment even they were fasted for $2 \mathrm{~h}$, and some bacteria even need few days to grow on the medium.
All the bacterial isolates were subjected for Catalase and IMVIC test. Changes in color of the media or broth and bubble formation after adding reagent for particular test which indicated positive results for that particular test. Anand et al.(2009) obtained eleven isolates from digestive tract of Bombyxmori and labelled as Isolate 1 to 11 . They characterized them morphologically and 
biochemically. Totally nine isolates for catalase test, nine isolates for citrate utilization test, six Isolates for Indole production test and Six isolates for methyl red test and five isolates for Voges-proskauer test shown positive result.

Totally ten bacteria strains were cultured from larval gut and six isolates were identified through molecular approach. The bacteria isolates identified after sequencing from the larvae of DBM were Serratia marcescens, Serratia nematodiphila, Serratia sp., and Myroidesodoratus. Among these Serratia sp was most predominant (Table 3). The cultureindependent bacteria, Enterococcus sp., were the main component of $P$. xylostella gut microbiota in the laboratory (Raymond et al., 2008). In the larval gut of other lepidopterous insects, such as the small white butterfly (Pierisrapae L.), Proteobacteria was the most highly represented phylum (Robinson et al., 2010).

\section{Acknowledgement}

I am greatful to Division of Agricultural Microbiology for giving opportunity to does this research work and also thankfull to Division of Agricultural Entomology, University of Agricultural Sciences, Bengaluru, India, for providing me with all the required facilities to complete my research programme.

\section{References}

Anand, A. A. P., Vennison, S. J., Sankar, S. G., Prabhu, D. I. G., Vasan, P. T., Raghuraman, T., Geoffrey, C. J. AND Vendan, S. E., 2009, Isolation and characterization of bacteria from the gut of Bombyxmori that degrade cellulose, xylan, pectin and starch and their impact on digestion. J. Insect Sci., 10(1): 107.
Benson, H.J., 2002, Microbiological applications. pp. 170-200. Boston, MA: McGraw Hill.

Berg, R.D., 1996, The indigenous gastrointestinal microflora. Trends Microbiol., 4: 430-435.

Brune, A., 2014, Symbiotic digestion of lignocellulose in termite guts. Nat. Rev. Microbiol., 12: 168-180.

Dillon, R.J. and Charnley, A.K., 1996, Colonization of the guts of germ-free desert locusts, Schistocerca gregaria, by the bacterium Panto eaagglomerans. J. Invertebr. Path., 67: 11-14.

Dillon, R. J. and Dillon, V. M., 2004, The gut bacteria of insects: Nonpathogenic interactions. Annu. Rev. Entomol., 49: 71-92.

Genta, F.A., Dillon, R.J., Terra, W.R. and Ferreira, C., 2006, Potential role for gut microbiota in cell wall digestion and glucoside detoxification in Tenebriomolitor larvae. J. Invertebr. Path., 52: 593-601.

Hunt, J. and Charnley, A. K., 1981, Abundance and distribution of the gut flora of the desert locust. Schistocerca gregaria. J. Invertebr. Pathol., 38: 378-385.

Lin, Xiao-Li., Pan, Qin-Jian., Tian, HongGang., Douglas, E. Angela and Liu, Tong-Xian., 2014, Bacteria abundance and diversity of different life stages of Plutella xylostella (Lepidoptera: Plutellidae), revealed by bacteria culture-dependent and PCR-DGGE methods. Insect Sci., 00: 1-11.

Liu, M. Y. and Tzeng, Y. J., 1984, Rearing diamondback moth (Lepidoptera: Yponomuetidae) on rape seedling by modification of the Koshihara and yamada method. J. Econ. Entomol., 77 (6): 1608-1609.

Rajagopal, R., 2009, Beneficial interactions between insects and gut bacteria. 
Indian J. Microbiol., 49: 114-119.

Raymond, B., West, S.A., Griffin, A.S. and Bonsall, M.B., 2008, The dynamics of cooperative bacterial virulence in the field. Sci., 337: 85-88.

Robinson, C.J., Schloss, P., Ramos, Y., Raffa, K. and Handelsman, J., 2010, Robustness of the bacterial community in the cabbage white butterfly larvalmidgut. Microbial Ecology, 59:199-211.

Saeed, R., Ali, H.S., Sarfraz, A. S. and Syed, M.Z., 2010, Effect of different host plants on the fitness of diamondback moth, Plutella xylostella (Lepidoptera: Plutellidae). Crop Protection, 29: 178-182.

\section{How to cite this article:}

Vijaykumar, W., R. Muthuraju, B. Shivanna, K. Archana and Nalini, B.S. 2019. Isolation, Characterization and Molecular Identification of Culturable Gut Bacteria in Diamondback Moth, Plutella xylostella (Linnaeus). Int.J.Curr.Microbiol.App.Sci. 8(02): 3291-3298. doi: https://doi.org/10.20546/ijcmas.2019.802.384 